\title{
How small cities affect the biodiversity of ground-dwelling mammals and the relevance of this knowledge in planning urban land expansion in terms of urban wildlife
}

\author{
Rafal Lopucki ${ }^{1}$ - Ignacy Kitowski ${ }^{2}$ \\ Published online: 3 January 2017 \\ (C) The Author(s) 2016. This article is published with open access at Springerlink.com
}

\begin{abstract}
Fundamental principles regarding urban biodiversity are based on studies conducted in large cities. However we cannot know whether the same phenomena occur in smaller cities or how small cities affect biodiversity. Small cities are an inherent element of urbanization and in the future, most global urban growth is expected to take place in small and mediumsized cities. Understanding the effects of small cities on biodiversity will be an important aspect in planning urban land expansion. Our study examined the effects of a small city on communities of small ground-dwelling mammals on 41 sites arranged in a four step gradient of urbanization. In 6700 trapdays, we caught 2333 individuals comprising 15 species. In the downtown area the same phenomena as those described for large cities were observed: a reduction in species richness and diversity, a decline in the abundance of urban sensitive species and an increase in synurbic species. However, in contrast to large city studies, green areas outside the downtown area did not differ from rural sites in small mammal population parameters. This phenomenon of relatively unchanged fauna outside the downtown area shows that small cities have the potential to maintain a high level of diversity of small grounddwelling mammals if appropriate planning of further building expansion is implemented. More studies of small cities are
\end{abstract}

Rafał Łopucki

lopucki@kul.pl

Ignacy Kitowski

ignacyk@autograf.pl

1 Center for Interdisciplinary Research, The John Paul II Catholic University of Lublin, Konstantynów 1J, 20-708 Lublin, Poland

2 State School of Higher Education in Chelm, Pocztowa 54, 22-100 Chełm, Poland needed to better assess their impact on biodiversity. This knowledge can then be applied in better planning for urban wildlife. Generalizations based solely on large city studies are inadequate and may lead to incomplete or inappropriate conservation strategies for small cities.

Key words Urbanization - Urban biodiversity . Small mammals $\cdot$ Species richness $\cdot$ Synurbic species . Urban planning

\section{Introduction}

The world is increasingly urban and cities are growing twice as fast in terms of land area as they are in terms of population (Angel et al. 2011). Consequently, between 2000 and 2030, global urban areas will triple and hundreds of thousands of additional square kilometres will be transformed for urban type land use (Angel et al. 2011; Seto et al. 2012; UN 2015). Cities are relatively new and specific ecosystems characterized by fragmented and disturbed environments, high densities of anthropogenic structures and impervious surfaces (Rebele 1994; Hobbs et al. 2006; Aronson et al. 2014). In such ecosystems only certain representatives of the native flora and fauna are able to exist.

Many studies have found that within cities, native flora and fauna communities are usually radically altered in terms of species composition, abundance, richness and evenness (Nilon and Pais 1997; van der Ree and McCarthy 2005; Gagné and Fahrig 2011; Faeth et al. 2011; Jones and Leather 2012; Aronson et al. 2014; Lattman et al. 2014). In the case of urban fauna, the main effects of urbanization are: biotic homogenization - a decrease in richness and diversity of fauna species along with the degree of urbanization (e.g. McKinney 2008; Cavia et al. 2009; Faeth et al. 2011); adaptation of some 
species (known as synurbic) to specific urban conditions (Luniak 2004; Francis and Chadwick 2012); changes in biocenotic relationships - lower pressure from predators and competitors (e.g. Lepczyk et al. 2003; Major et al. 1996), extension of breeding seasons, increase of abundance, and a decreased in territory in species that are urban adapted (Gliwicz et al. 1994) There is also reduced fear of humans and tolerance to urban noise (Ditchkoff et al. 2006; Møller 2009).

The effects of urbanisation on biotic communities have commonly been studied across urban-rural gradients (McDonnell and Pickett 1990; McDonnell and Hahs 2008; McKinney 2008; Niemelä and Kotze 2009; Cavia et al. 2009; Vergnes et al. 2014). This approach has the advantages of being intuitive and easily measured. In their review of urban-rural gradient analyses, McDonnell and Hahs (2008) noted that the concept of urbanization gradients is based on the well-established application of gradient analysis tools in order to understand the ecology and distribution of organisms in response to various changes to the environment. They also pointed out that typically, the most intense 'urban' environmental conditions occur in the older, more man-modified centres of cities, with decreasing 'urban' effects further away from city centres. Such gradients occur all over the world, and they provide a useful framework for comparative studies on a global scale, as they generally reflect similar anthropogenic patterns and processes (Niemelä and Kotze 2009). Comparative analysis of studies that had explicitly taken a gradient approach showed that the relationship between biodiversity and the urban-rural gradient follows a wide range of predictive curves, depending mainly on the taxa studied, e.g. negative response, positive response, punctuated response, intermediate response, bimodal response and no response (McDonnell and Hahs 2008). Apart from urbanization gradient analysis, there are other ecological frameworks that are also useful in understanding the ecology of urbanized landscapes, e.g. patch dynamics or meta-analysis (McDonnell and Hahs 2008; Beninde et al. 2015).

Studies concerning the influence of urbanization on wildlife are mainly conducted in large cities occupying hundreds or thousands of square kilometres and inhabited by hundreds of thousands or millions of people. This is clearly visible in review papers, where examples from smaller cities are very scarce (Niemelä and Kotze 2009; Faeth et al. 2011; Aronson et al. 2014; Bonthoux et al. 2014). The possible reason behind favouring large cities in research is the fact that large metropolitan areas represent the peak of urbanization and therefore can be used as appropriate models to analyse the effects of habitat fragmentation in the extreme (Vignoli et al. 2009). In consequence, the basic generalizations and laws of urban ecology have been formulated on the basis of large city studies.

By contrast, we do not know whether the same phenomena occur in smaller cities or how small cities affect biodiversity. There exists no common global definition of a small city in terms of size (population, urban area). Global standards cannot be applied to all regions or countries. For example, while considered medium-sized by global standards ( 1 to 5 million inhabitants), some cities were in fact the largest cities in the country in 79 cases (UN 2015). We propose that a 'small city' can be considered one with a population of fewer than 100,000 and an urban area smaller than $100 \mathrm{~km}^{2}$.

Small cities are an important element in urbanization, much more common than large cities, both in number, and in total occupied area. For example in central Europe, in Germany, Poland and Ukraine, there are 27 large cities (with more than 500,000 inhabitants), 165 medium-sized cities $(100,000$ 500,000 inhabitants) and 754 small cities (25,000-99,999 inhabitants) (WPR 2015). In these countries, small cities occupy 3-7 times more land than their large cities. Moreover, in the near future, in many developing countries of the world most of the urban growth is expected to take place in small and medium-sized cities (Sun et al. 2012; Secretariat of the CBD 2012). Understanding the effects of small cities on biodiversity will be important in planning urban land expansion. It will enable, for example, early introduction of measures that could reduce the negative effects of urbanization seen in mediumsized and large cities.

The role which small cities play in wildlife conservation is poorly understood. There are few studies of biodiversity in small cities, e.g. for plants (Wang et al. 2014), birds (Ferenc et al. 2014; Sorace and Gustin 2010; Helden et al. 2012), fish (Peressin and Cetra 2014) and insects (Magura et al. 2004; Elek and Lövei 2007; Helden et al. 2012, ). Indeed there is a lack of review articles on this subject and many groups of animals have yet to be studied in terms of the effects of urbanization. Much more needs to be done in order to fully assess the impact of small cities on biodiversity (Wang et al. 2014).

The aim of this study was to evaluate the impact of the urbanization patterns of a small city on a community of small ground-dwelling mammals. From studies of large cities (Sorace 2001; Elvers and Elvers 1984; Gortat et al. 2014; Frynta et al. 1994; Cavia et al. 2009; Garden et al. 2007, 2010; Baker et al. 2003), we know that most native species of small mammals become extinct or decrease in number (urbanization-sensitive species), and only a few species are able to adapt to urban conditions (synurbic species). The main factors determining the occurrence of small mammals in large cities are also known: small mammals prefer habitats with dense undergrowth or ground cover and with low levels of spatial isolation (Babińska-Werka et al. 1979; Cavia et al. 2009; Gomes et al. 2011; Łopucki et al. 2013). We expected that in small cities, where even downtown green areas are relatively close to the outskirts and green corridors allow movement of small ground-dwelling mammals to and from the city, the small mammals community would be only minimally affected. We tested the null hypothesis of no effect (negative or positive) of small cities on communities of small 
mammals (i.e. no differences in species richness, species diversity, community composition or relative abundance regardless of the location in the urban gradient).

\section{Materials and methods}

\section{Study area}

The study was carried out in Poland (Europe), in the city of Chełm $\left(51^{\circ} 07^{\prime} \mathrm{N}, 23^{\circ} 28^{\prime} \mathrm{E}\right)$ and its surrounding area in an agricultural landscape up to $40 \mathrm{~km}$ from the administrative boundaries of the city. We selected Chełm as the study area because it is situated in a region where similar surveys of urban fauna have been conducted in large and mediumsized cities (Andrzejewski et al. 1978; Babińska-Werka et al. 1979; Gortat et al. 2014 for Warsaw and Łopucki et al. 2013, Łopucki and Kiersztyn 2015 for Lublin). This enabled us to make reliable comparisons of our results with data from larger cities (Warsaw, Lublin and Chełm have a similar small mammals fauna).

Chełm has an area of $35.5 \mathrm{~km}^{2}$ and a population of 65,643 (CSO 2014). It was established over 600 years ago. Nowadays, built-up areas (i.e. commercial buildings, housing estates, road networks and a large industrial estate in the eastern part of the city) occupy about $51 \%$ of the area. The remaining space consists of green areas under various types of management (e.g. parks and forests (12\%), agricultural fields, gardens, allotments and orchards (17\%), meadows and wetlands (7\%), waterways (1\%) and unmanaged areas (12\%) (information supplied by Chełm City Council). The small size of the city means that green areas even in the centre of the city lie relatively close to the outskirts of the city, at a distance of at most $1.5 \mathrm{~km}$ (Fig. 1).

The lands around Chełm are agricultural with $(<18 \%)$ wooded areas and a low level of urbanization. The region is characterized by hot summers (mean temperatures above $17^{\circ} \mathrm{C}$ ), cold winters (mean temperatures below $-3{ }^{\circ} \mathrm{C}$ ) and mean annual precipitation of $550 \mathrm{~mm}$ (Lopucki and Kitowski 2014).

\section{Trapping sites}

Small mammals were captured in 21 green areas in the city (urban sites) and 20 sites beyond the city limits (rural sites). The method chosen was similar to that used in the Warsaw (Andrzejewski et al. 1978; Babińska-Werka et al. 1979; Gortat et al. 2014) and Lublin (Łopucki et al. 2013; Łopucki and Kiersztyn 2015), enabling us to make reliable comparisons of our results with data from those larger cities. Study sites were divided into four groups according to their location relative to the city centre. Below is a description of those groups.

1. Downtown sites - seven green areas situated in the oldest part of the city (Fig. 1, Table 1). All green areas that provided suitable habitat for small mammals (i.e. had relatively dense undergrowth or ground cover (BabińskaWerka et al. 1979)) were included. Each downtown site was isolated by buildings and roads and had no direct connection to green areas surrounding the city.

2. Green corridor sites - seven sites situated near the downtown area but within two potential movement corridors: along the valley of the Uherka River and the vegetation alongside the railway line (Fig. 1, Table 1). Representative green areas were chosen from the major types of green area occurring in this zone. The linear nature of the river
Fig. 1 Location of study sites in the city. The numbers refer to sites numbers in Table 1

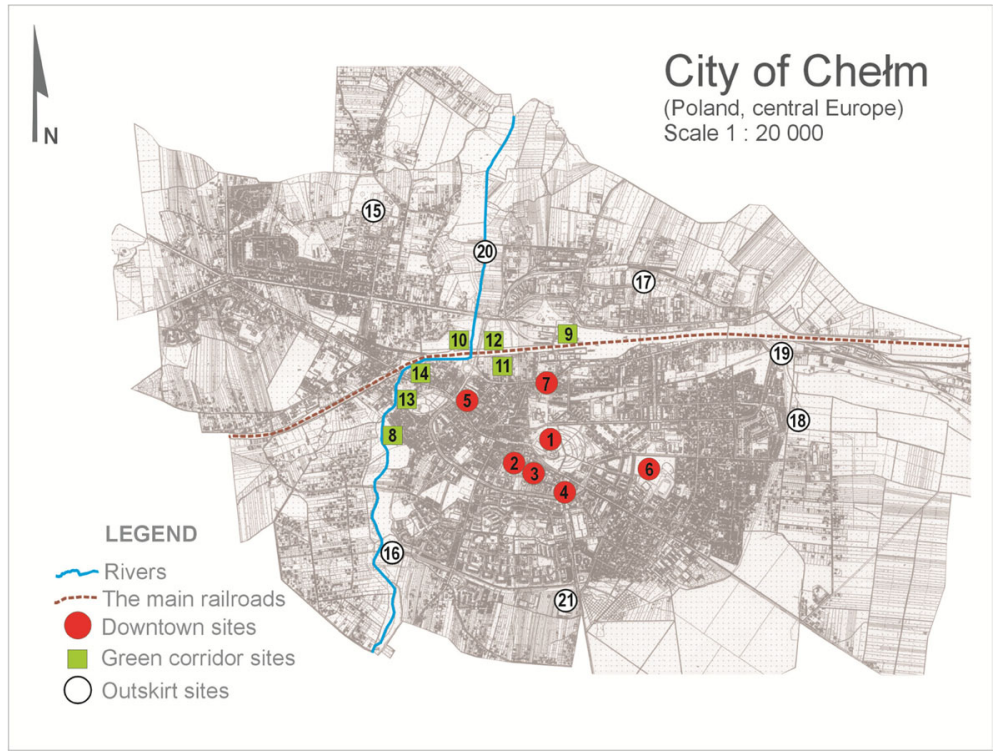


Table 1 Characteristics of the study area, study years and trapping effort within the city and rural sites. Site number refers to the number of sites in Fig. 1

\begin{tabular}{|c|c|c|c|c|c|}
\hline Location & Patch number and type of management & Area [ha] & Trapping years & $\begin{array}{l}\text { Trapping effort } \\
\text { [trap-days] }\end{array}$ & No. of trapped indiv. \\
\hline \multirow[t]{7}{*}{ City downtown } & (1) city park & 4.2 & 2013,2014 & 300 & 50 \\
\hline & $\begin{array}{l}\text { (2) unmanaged area with ruderal vegetation } \\
\text { and old neglected orchard }\end{array}$ & 0.25 & 2013,2014 & 200 & 27 \\
\hline & (3) garden and old neglected orchard & 0.22 & 2013,2014 & 200 & 46 \\
\hline & $\begin{array}{l}\text { (4) unmanaged area with ruderal vegetation, } \\
\text { grass and shrubs }\end{array}$ & 0.75 & 2013,2014 & 300 & 57 \\
\hline & $\begin{array}{l}\text { (5) unmanaged area with ruderal vegetation } \\
\text { and old neglected orchard }\end{array}$ & 0.4 & 2014 & 100 & 17 \\
\hline & $\begin{array}{l}\text { (6) unmanaged area with herbs, } \\
\text { grass and shrubs }\end{array}$ & 5.7 & 2013,2014 & 300 & 103 \\
\hline & (7) old neglected garden & 0.34 & 2013,2014 & 200 & 14 \\
\hline \multirow{7}{*}{$\begin{array}{l}\text { Green corridors near } \\
\text { downtown }\end{array}$} & (8) moist sedgeland in the river valley & 0.7 & 2013,2014 & 200 & 33 \\
\hline & $\begin{array}{l}\text { (9) old railway siding under secondary } \\
\text { succession - unmanaged area with } \\
\text { grasses and shrubs }\end{array}$ & 1.1 & 2013,2014 & 200 & 64 \\
\hline & $\begin{array}{l}\text { (10) moist sedgeland in the river } \\
\text { valley and allotments }\end{array}$ & 1.9 & 2013,2014 & 200 & 78 \\
\hline & $\begin{array}{l}\text { (11) unmanaged area with ruderal vegetation } \\
\text { and old neglected orchard }\end{array}$ & 3 & 2013,2014 & 200 & 88 \\
\hline & (12) wooded area and allotments & 2.9 & 2013,2014 & 200 & 94 \\
\hline & (13) city park & 1.8 & 2013,2014 & 200 & 8 \\
\hline & $\begin{array}{l}\text { (14) partly wooded unmanaged area with } \\
\text { ruderal vegetation }\end{array}$ & 0.9 & 2013,2014 & 200 & 54 \\
\hline \multirow[t]{7}{*}{ Outskirts of the city } & $\begin{array}{l}\text { (15) unmanaged area within a complex } \\
\text { of abandoned buildings under } \\
\text { secondary succession }\end{array}$ & 1.9 & 2013,2014 & 200 & 78 \\
\hline & (16) moist sedgeland in the river valley & 2.7 & 2013,2014 & 200 & 63 \\
\hline & $\begin{array}{l}\text { (17) unmanaged area with grasses and old } \\
\text { neglected orchard }\end{array}$ & 1.3 & 2013,2014 & 200 & 60 \\
\hline & $\begin{array}{l}\text { (18) unmanaged postindustrial area with } \\
\text { ruderal vegetation and shrubs }\end{array}$ & 2.8 & 2013,2014 & 200 & 87 \\
\hline & $\begin{array}{l}\text { (19) unmanaged area with herbs, } \\
\text { grasses and shrubs }\end{array}$ & 1.9 & 2013,2014 & 200 & 68 \\
\hline & $\begin{array}{l}\text { (20) moist sedgeland and unmanaged area } \\
\text { with herbs and grasses in the river valley }\end{array}$ & 2.2 & 2013,2014 & 200 & 67 \\
\hline & $\begin{array}{l}\text { (21) ruderal and segetal vegetation within } \\
\text { cultivated fields }\end{array}$ & 1.7 & 2013,2014 & 200 & 72 \\
\hline \multirow[t]{2}{*}{ Rural areas } & $\begin{array}{l}\text { Twenty sites with natural and semi-natural } \\
\text { vegetation in agricultural landscape: narrow } \\
\text { belts of vegetation with grasses, herbs, and } \\
\text { sometimes shrubs separating agricultural plots, } \\
\text { shoulders of dirt roads in arable fields, } \\
\text { wastelands - desolate or barren uncultivated } \\
\text { area with short vegetation, shrubs or partly } \\
\text { wooded, small forests surrounded by arable } \\
\text { fields, moisture meadow with grasses and } \\
\text { sedges near small rivers or drainage ditch. }\end{array}$ & not determined $*$ & 2013,2014 & 2300 & 1120 \\
\hline & & & Total & 6700 & 2333 \\
\hline
\end{tabular}

*Due to a linear character of most the studied rural sites the area of this sites were not determined

valley and the railway line meant that the sites were not isolated from each other or the city's surrounding areas.

3. Outskirt sites - seven sites situated at the edge of the builtup area (Fig. 1, Table 1). Representative sites were chosen from the major types of green area in this zone. The outskirt sites were not isolated from the city's surrounding areas.
4. Rural sites - 20 sites located in the agricultural landscape around Chełm (Table 1). Trapping was conducted in representative types of habitat occurring in this landscape, i.e. in sites with various heights of vegetation: short (with herbs, grasses, sedges or segetal and ruderal vegetation), medium (with shrubs, mainly hawthorn, willow, rose, 
dogwood, blackthorn), and high (in small woodlands). Additionally, the selected study sites were characterized by different moisture regimes (from xerothermic grasslands to moist sedgeland or small alder woodland). The proportion of dry to wet habitats was similar within and without the city.

\section{Trapping scheme}

Small mammals were captured in two types of live trap with food bait: wooden box traps $(90 \times 80 \times 200 \mathrm{~mm})$ and metal multi-capture Ugglan traps $(60 \times 90 \times 240 \mathrm{~mm})$. Traps were set along a transect consisting of 15 wooden box traps and 10 Ugglan traps spaced at $15 \mathrm{~m}$ intervals. Traps were monitored twice a day. The trapping session on each site lasted 4 days, i.e. 100 trap-days ( 25 traps $\times 4$ days) per site. Ten sites were usually set up with traps at the same time. Captured animals were described in terms of species, sex (where possible), reproductive activity and body mass (with accuracy to $1 \mathrm{~g}$ ). The sex of shrews was not determined due to the lack of sexual dimorphism. Newly captured individuals were marked by fur clipping. After capturing, all individuals were released at the site of capture. Trapping sessions were carried out in the summer and autumn (from July to November) of 2013 and 2014. Table 1 presents detailed information on trapping years, number of trap days and number of animals caught at each study site.

\section{Data analysis}

Communities of small mammals in urban and rural sites were analysed on the basis of the following parameters calculated independently for each of 41 study sites:

(1) relative abundance of small mammals, defined as the number of individuals (all species) captured per 100 trap-days.

(2) species richness, defined as the number of recorded species.

(3) species diversity, calculated using the Shannon-Wiener index $\left(\mathrm{H}^{\prime}\right)$ using a natural logarithm.

(4) proportion (\%) of shrews (family Soricidae) in the small mammal community. Shrews are known as an urban sensitive species and can be considered useful indicators of the impact of urbanization (Vergnes et al. 2013; Łopucki and Kitowski 2014).

(5) proportion (\%) of voles (rodents belonging to the family Cricetidae). Voles are usually rare in urban environments and can be considered an urban sensitive species and indicators of the impact of urbanization (Lopucki et al. 2013; Gortat et al. 2014).
(6) proportion (\%) of individuals of the Apodemus genus (family Muridae). In Europe Apodemus is known as the most synurbic genus (Andrzejewski et al. 1978; Baker et al. 2003; Łopucki et al. 2013; Gortat et al. 2014).

(7) proportion (\%) of striped field mice Apodemus agrarius (Pallas, 1771). A. agrarius is known as the most synurbic rodent species in Poland (Andrzejewski et al. 1978; Łopucki et al. 2013; Gortat et al. 2014).

All of the above parameters were analysed in a four-step gradient of urbanization (i.e. downtown, green corridors located near downtown, city outskirts and rural sites) using a nonparametric one-way ANOVA by ranks (Kruskal-Wallis test for the mean ranks) with a post hoc test ( $z^{\prime}$ value) for mean ranks. Statistical tests were performed by means of the software STATISTICA version 10.0.

\section{Results}

In 6700 trap-days, 2333 individuals of 15 species were captured, including 1213 individuals of 13 species within the city and 1120 individuals of 14 species in rural areas. Both in the city and in rural areas, small mammals were found in all study sites.

Small mammal abundance differed significantly along the four-step gradient of urbanization (Kruskal-Wallis test: $\left.H_{(3)}=20.695, p=0.0001, N=41\right)$. Post hoc test ( $z^{\prime}$ value) for mean ranks showed that small mammals were significantly less abundant in downtown than rural sites $\left(z^{\prime}=4.315\right.$, $p=0.0000$ ). There were no statistically significant differences between the remaining habitat types (Fig. 2).

Species richness of small mammals differed significantly across gradient of urbanization (Kruskal-Wallis test: $\left.\mathrm{H}_{(3)}=17.013, p=0.0007, N=41\right)$. Post hoc test ( $\mathrm{z}^{\prime}$ value) for mean ranks showed that significantly fewer species occurred in downtown habitats than in the outskirts $\left(\mathrm{z}^{\prime}=3.852, p=0.0007\right)$ or rural sites $\left(\mathrm{z}^{\prime}=3.245\right.$, $p=0.007)$. There were no statistically significant differences between the remaining habitat types (Fig. 3a).

Species diversity $H^{\prime}$ indices for small mammal communities differed significantly across the four-step gradient of urbanization (Kruskal-Wallis test: $\mathrm{H}_{(3)}=16.682, p=0.0008$, $N=41$ ). Species diversity was the parameter that most clearly showed differences between site types. Post hoc tests ( $z^{\prime}$ value) for mean ranks showed that the index of species diversity in downtown sites was significantly lower than in corridors ( $\left.\mathrm{z}^{\prime}=2.66, p=0.0469\right)$, outskirts $\left(\mathrm{z}^{\prime}=3.736, p=0.0011\right)$ or rural sites $\left(\mathrm{z}^{\prime}=3.437, p=0.0035\right)$. Corridors, outskirts and rural sites had similar $H^{\prime}$ indices (Fig. 3b).

There were also significant differences in the proportions of shrews species (Kruskal-Wallis test: $\mathrm{H}_{(3)}=12.26$, $p=0.0065, N=41$ ). Urbanization-sensitive species rarely occurred in downtown Chełm (up to $4 \%$ ), whereas in the 
Fig. 2 Abundance of small mammals in particular groups of sites along the four-step gradient of urbanization. Significant differences $(*)$ was found between downtown and rural sites (post hoc test for mean ranks; $\mathrm{z}^{\prime}=4.315, p=0.0000$ )

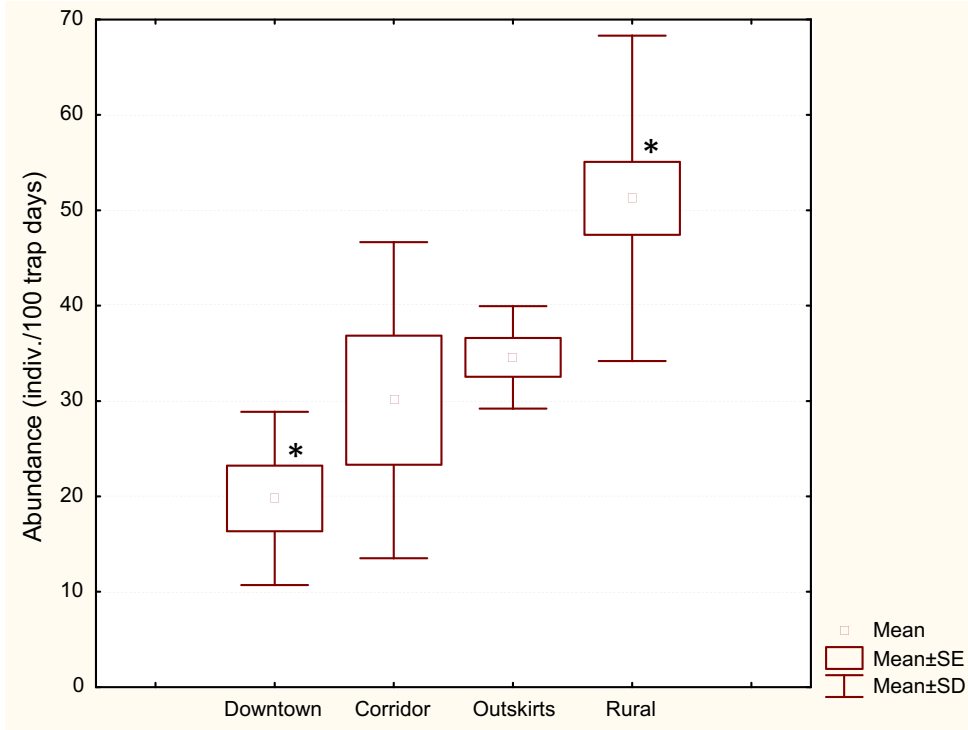

outskirts $\left(z^{\prime}=3.053, p=0.013\right)$ and rural sites $\left(z^{\prime}=3.023\right.$, $p=0.015$ ) the proportion of shrews in the small mammal community was higher (up to $32 \%$ ). The difference between downtown and corridor sites was also close to being of statistical significance $\left(z^{\prime}=2.512, p=0.072\right)$. There were no differences between corridor, outskirts and rural sites in any combinations (Fig. 4a). Crocidura leucodon (Hermann, 1780) was the only shrew species inhabiting green areas in the downtown sites.

Results similar to those for shrews were observed for voles, the second group of urban sensitive species. The proportion of voles differed significantly across the urbanization gradient (Kruskal-Wallis test: $\mathrm{H}_{(3)}=22.17, p=0.0001, N=41$ ). In downtown sites voles were significantly less abundant than in the outskirts $\left(z^{\prime}=3.163, p=0.0094\right)$ and rural sites ( $\left.z^{\prime}=4.47, p=0.0000\right)$. The proportion of voles in the small mammal community in rural sites amounted to $70 \%$, whereas in downtown sites the maximum was $3.5 \%$. In terms of percentages of voles, there were no differences between corridor, outskirts and rural sites in any combinations (Fig. 4b).

The proportion of synurbic species from the genus Apodemus (i.e. A. agrarius, A. flavicollis and A. sylvaticus) also differed significantly in the four-step gradient of urbanization (Kruskal-Wallis test: $\mathrm{H}_{(3)}=19.241, p=0.0002$, $N=41$ ). Post hoc test (z' value) for mean ranks showed that the numbers of rodents from this genus were significantly higher in the mammal communities in the downtown than in the outskirts $\left(z^{\prime}=3.206, p=0.008\right)$ and rural sites $\left(z^{\prime}=4.27\right.$, $p=0.0001)$. In downtown sites the lowest recorded proportion of Apodemus sp. was $93 \%$. In rural sites the figure was $2.3 \%$. There were no differences between the remaining sites (Fig. 5a).

The proportion of the synurbic species Apodemus agrarius differed significantly in the analysed four-step gradient of urbanization (Kruskal-Wallis test: $\mathrm{H}_{(3)}=11,562, p=0.009$, $N=41$ ). Post hoc test (z' value) for mean ranks showed that A. agrarius represented a significantly higher proportion of the rodent community in downtown compared to rural sites $\left(z^{\prime}=3.188, p=0.0086\right)$. The difference between "downtown corridor" sites and "downtown - outskirts" sites were also close to being of statistical significance $\left(z^{\prime}=2.634\right.$, $p=0.0506$ and $z^{\prime}=2.445, p=0.0868$ respectively). There were no differences between the remaining sites (Fig. 5b).

\section{Discussion}

We hypothesized that urbanization patterns of a small city have non-significant effects on small mammals. The green areas in small cities are relatively close to the outskirts and secondly, green corridors allow movement of small grounddwelling mammals to and from the city. Therefore, only a slight reduction in biodiversity and species richness along the urbanization gradient in a small city may be expected.

\section{Small city downtown areas}

This study shows that in the downtown of a small city negative effects of urbanization on small ground-dwelling mammals did occur and are similar to the phenomena described for medium-sized and large cities (e.g. Andrzejewski et al. 1978; Frynta et al. 1994; Cavia et al. 2009; Gortat et al. 2014). These effects are expressed as a reduction in species richness and diversity, a radical decline in abundance of urban sensitive species and an increase in the proportion of synurbic species.

In downtown Chełm, as in larger European cities, a process of synurbization of small mammals was observed. The synurbic species are defined as those adapted to specific urban 
Fig. 3 Species richness (a) and diversity $H$-index (b) in groups of sites along the four-step gradient of urbanization. Significant differences (post hoc test for mean ranks) for species richness: $* \mathrm{z}^{\prime}=3.852$, $p=0.0007 ; * * z^{\prime}=3.245$, $p=0.007$; and for diversity $\mathrm{H}$ index: * $z^{\prime}=2.660, p=0.0468$; $* * \mathrm{z}^{\prime}=3.736, p=0.0011$; *** $\mathrm{z}^{\prime}=3.437, p=0.0035$
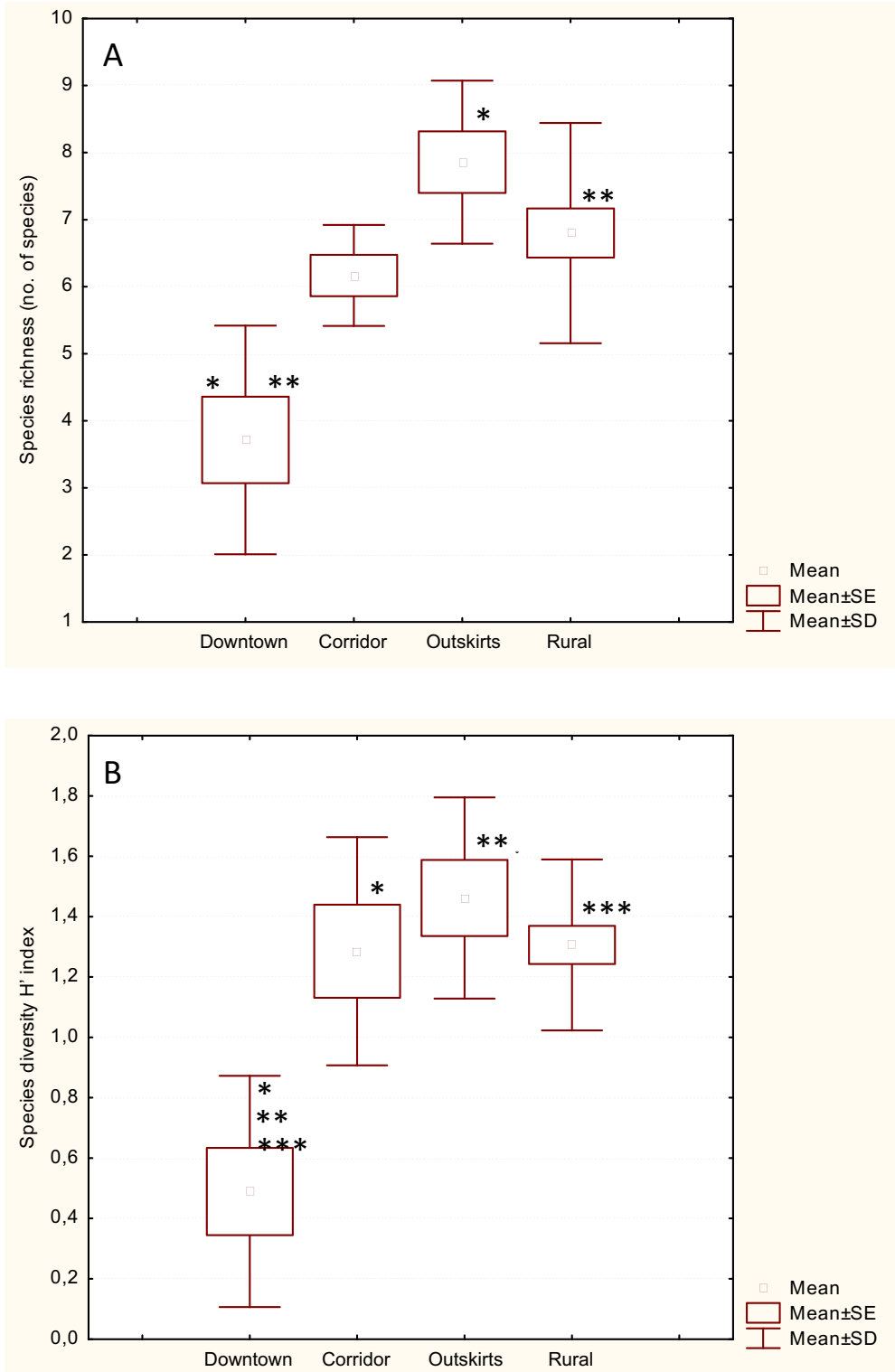

conditions, but still existing in the wild (Luniak 2004). Francis and Chadwick (2012) noted in particular that synurbic species demonstrate a higher degree of abundance in urban compared to rural areas. In downtown Chełm the most numerous small mammals were mice of the genus Apodemus: A. agrarius, A. flavicollis and A. sylvaticus, with these representing 93$100 \%$ of the community. Among these, A. agrarius was found to be the most synurbic species. In other European cities the same three species of mice are considered synurbic, but which species dominates depends on their geographical range (Andrzejewski et al. 1978; Babińska-Werka et al. 1979; Dickman and Doncaster 1989; Frynta et al. 1994; Baker et al. 2003; Baranauskas et al. 2005; Łopucki et al. 2013; Gortat et al. 2014).

Moreover, in the downtown area of the small city studied we found radical declines in the richness and abundance of urban sensitive species. In our study, shrews were found to be most sensitive to urbanization, followed by voles. Out of the four shrew species and five vole species occurring in rural areas, only one shrew C. leucodon and one vole, Microtus arvalis (Pallas, 1778), were captured in downtown green areas. This is consistent with other studies, which have shown that shrews are particularly vulnerable to the negative impact of urbanization and rapidly declined in number along an urbanization gradient (Frynta et al. 1994; Vergnes et al. 2013; Łopucki and Kitowski 2014) and only the genus Crocidura can be found in green areas in the centre of a city (Frynta et al. 1994; Łopucki and Kitowski 2014).

To summarise, our study showed that the downtown section of a small city had sufficient area (in the case of Chełm this was approximately $2.5 \mathrm{~km}^{2}$ ) and a sufficiently strong impact to modify the native small mammal community and 
Fig. 4 Proportion of urban sensitive species in groups of sites along the four-step gradient of urbanization: for shrews species (a) and for vole species (b). Significant differences (post hoc test for mean ranks) for (a):

$* z^{\prime}=3.053, p=0.0135$;

** $\mathrm{z}^{\prime}=3.023, p=0.015$ and for $(\mathbf{b}):{ }^{*} \mathrm{z}^{\prime}=3.162$, $p=0.0094 ; * * \mathrm{z}^{\prime}=4.47$, $p=0.0000$
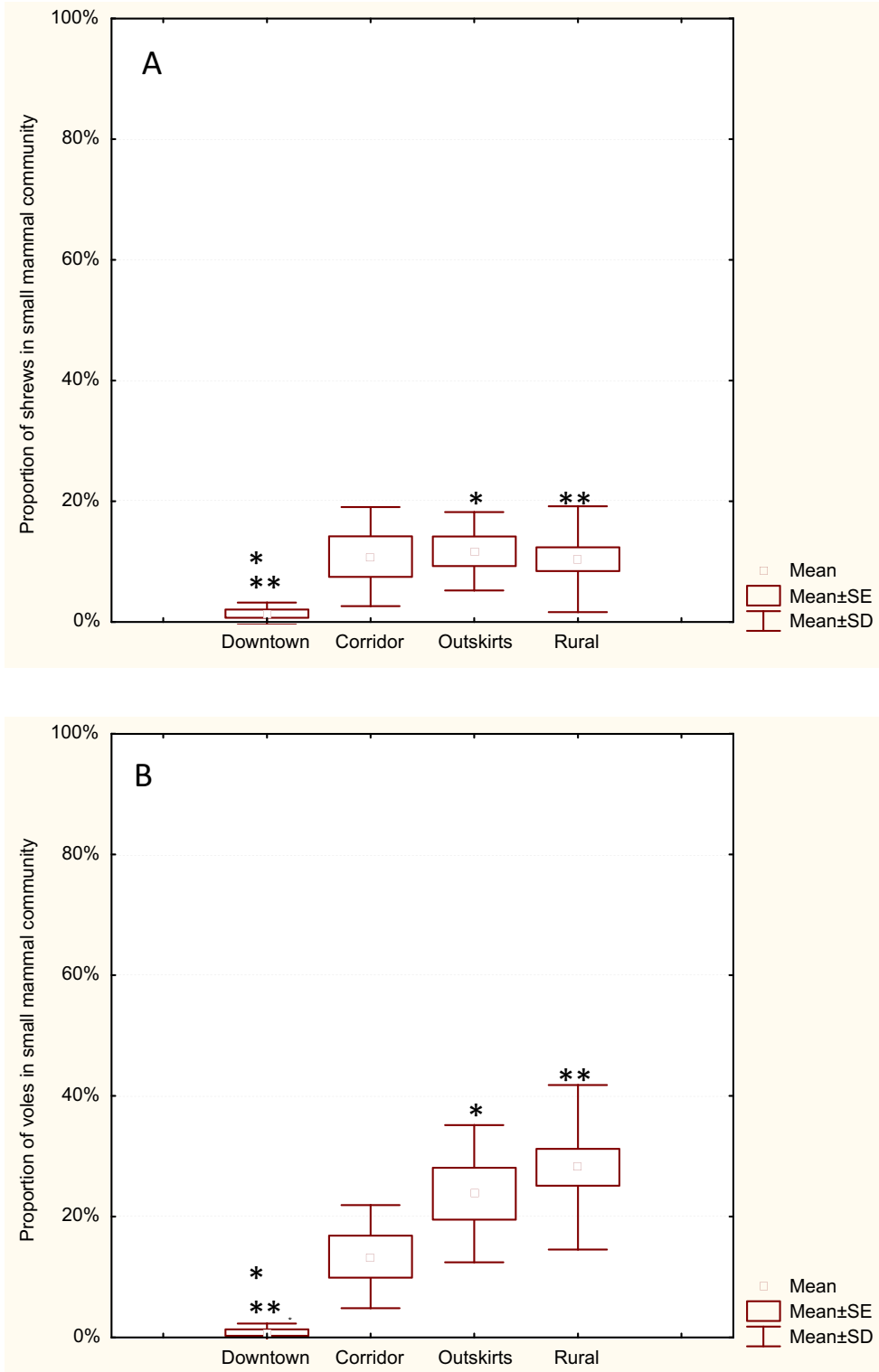

create an urban-biased species composition, typical for this region of Europe.

\section{Small city outskirts and green corridors}

In large and medium-sized cities the effects of urbanization on the small ground-dwelling mammal community are not limited to the city centre. Studies of larger cities clearly demonstrate that in areas outside the city centre urbanization has a negative impact on the richness and biodiversity of small mammal species and even green areas located on the outskirts of a city (where urban species richness and diversity were relatively high) differed significantly from rural areas (Cavia et al. 2009; Łopucki et al. 2013; Gortat et al. 2014). Such observations are consistent with the predictive curves presented in the review by McDonnell and Hahs (2008) showing a "negative response" of urban biodiversity along the urban-rural gradient.

In Chelm we did not observe this phenomenon and the reactions of small mammals to gradients of urbanization are of a rather "punctuated" nature (sensu McDonnell and Hahs 2008). Green areas outside the downtown section, both in green corridors and outskirts sites, did not differ from rural sites with regard to any studied parameter. This means that transformation of small mammal communities outside the downtown section of a small city is non-significant, and these areas can be inhabited even by species sensitive to urbanization. The probable reason for this lies in the maintenance of reciprocal connections among green areas (the role of green corridors) and the relatively short distances to the outskirts of a 
Fig. 5 Proportion of urban biased (synurbic) species in groups of sites along the fourstep gradient of urbanization: for all species belonging to genus of Apodemus (a) and for the most abundant synurbic species - A. agrarius (b). Significant differences (post hoc test for mean ranks) for (a): $*^{*} \mathrm{z}^{\prime}=3.206, p=0.0081$; $* * \mathrm{z}^{\prime}=4.27, p=0.0001$; and for (b) ${ }^{*} \mathrm{z}^{\prime}=3.188, p=0.0086$
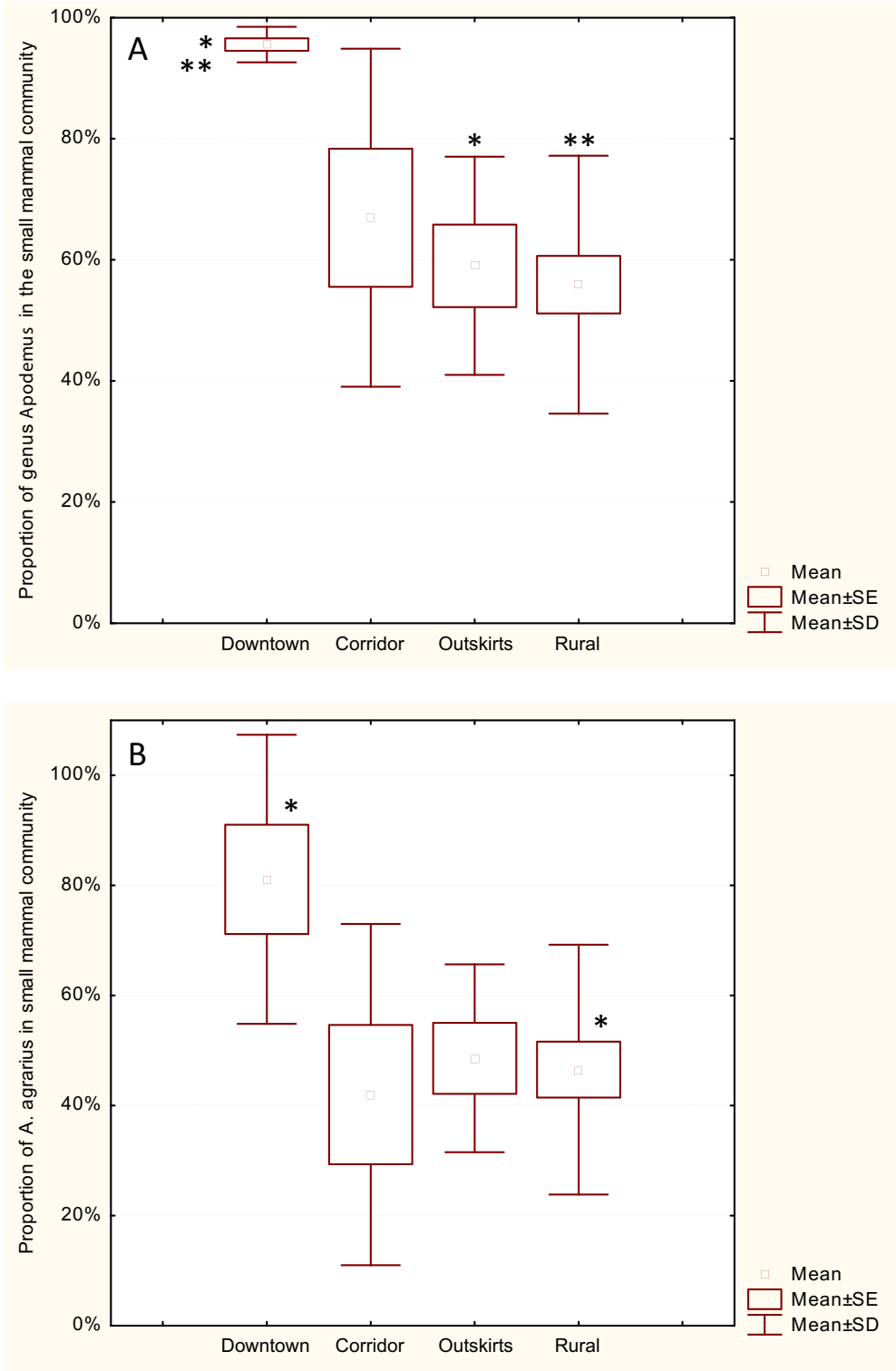

city of this size. This reinforces the observations by VanDruff and Rowse (1986), namely that the continuing existence of many species of small mammals in urbanized areas is dependent on a mosaic of habitats and land uses within the overall urban area, rather than on conditions found within specific green spaces. It is also important that smaller cities usually have relatively smaller areas of high human population density and in consequence a lower total human population density (e.g., in Chełm - 1856 inhabitants $/ \mathrm{km}^{2}$; in Warsaw 3334 inhabitants $/ \mathrm{km}^{2}$ ) (CSO 2014) and the fact that areas outside the downtown section often consist of single family houses with gardens. Such areas are relatively friendly to small ground-dwelling mammals because gardens can be suitable habitats for these animals and do not restrict their movement (Baker et al. 2003). This is also consistent with studies by Colding (2007), who showed the role of ecological land-use complementation in maintaining biodiversity in urban areas, and studies by Fleury and Brown (1997), Mahan and O'Connell (2005), Angold et al. (2006) and Vergnes et al. (2013) concerning the role of dispersal corridors.

\section{Maintaining biodiversity during urban growth}

As urbanization continues rapidly around the world, a better understanding of its ecological impact is critical in informing policy and practices to help guide the construction of cities (Sushinsky et al. 2013). Our study showed that a small city retained a relatively rich native fauna. Since intense urban growth is expected to take place also in small cities (Secretariat of the CBD 2012; Sun et al. 2012; UN 2015), in order to maintain the current diversity and population viability, it would clearly be best if ecological planning of such 
growth be implemented as soon as possible in city development. It will enable, for example, early introduction of measures that could reduce the negative effects of urbanization found in medium-sized and large cities. In large cities these measures (e.g. the ecological restoration of urban green systems) are usually much more costly and difficult to implement (Kong et al. 2010; Yu et al. 2012). In small cities such measures may be developed at the earliest stage of city development and include: the exclusion of habitat blocks from development, development of a system of corridors connecting green areas to each other and with rural areas, and statutory protection of the most valuable natural sites. These measures could ensure adequate amounts of green areas within urban areas, also in or near the city centre. In some cases these measures may also include habitat modifications that alter vegetation composition, the amount of canopy cover, the presence of ground cover and undergrowth, the amount of fallen woody material, and soil compaction. Garden et al. (2007) showed that habitat structure appears to be the most important factor determining assemblages of urban grounddwelling vertebrates. Finally, ecological land-use complementation (Colding 2007) in maintaining biodiversity in urban areas should be widely applied. It should also be noted that some studies pointed out that the impact of urban growth on animals distributions depend on the spatial pattern of urban growth, not just its extent and secondly, that the comparatively low ecological impact of compact urban growth depends crucially on maintaining high-quality interstitial green spaces between high-density developments (Sushinsky et al. 2013). If properly planned, compact urban growth can preserve large intact green spaces, and maintain a more ecologically heterogeneous city landscape that will support both urban-adapted and urban-sensitive species (Bryant 2006; Sandström et al. 2006; Sushinsky et al. 2013).

More studies of small cities are needed to better assess their impact on biodiversity. This knowledge can then be applied in better planning for urban wildlife. Generalizations based solely on large city studies are inadequate and may lead to incomplete or inappropriate conservation strategies for small cities.

\begin{abstract}
Acknowledgements The authors would like to thank the anonymous reviewers for their helpful and constructive comments that greatly contributed to improving the final version of the paper. We also are greatly indebted to Dr. David Ellis (Institute for Raptor Studies, Oracle, USA) for helpful critical comments on the first versions of manuscript and correction of English language.
\end{abstract}

Open Access This article is distributed under the terms of the Creative Commons Attribution 4.0 International License (http:// creativecommons.org/licenses/by/4.0/), which permits unrestricted use, distribution, and reproduction in any medium, provided you give appropriate credit to the original author(s) and the source, provide a link to the Creative Commons license, and indicate if changes were made.

\section{References}

Andrzejewski R, Babińska-Werka J, Gliwicz J, Goszczyński J (1978) Synurbization process in population of Apodemus agrarius. I. Characteristics of populations in urbanization gradient. Acta Theriol 23:341-358

Angel S, Parent J, Civco DL, Blei A, Potere D (2011) The dimensions of global urban expansion: estimates and projections for all countries, 2000-2050. Prog Plan 75:53-107

Angold PG, Sadler JP, Hill MO, Pullin A, Rushton S, Austin K, Small E, Wood B, Wadsworth R, Sanderson R, Thompson K (2006) Biodiversity in urban habitat patches. Sci Total Environ 360:196204

Aronson MFJ, La Sorte FA, Nilon CHH, Katti M, Goddard MA, Lepczyk CHA, Warren PS, Williams NSG, Cilliers S, Clarkson B, Dobbs C, Dolan R, Hedblom M, Klotz S, Kooijmans JL, Kühn J, MacGregorFors I, McDonnell M, Mörtberg U, Pyšek P, Siebert S, Sushinsky J, Werner P, Winter M (2014) A global analysis of the impacts of urbanization on bird and plant diversity reveals key anthropogenic drivers. Proc R Soc B 281:20133330

Babińska-Werka J, Gliwicz J, Goszczyński J (1979) Synurbization processes in an urban population of Apodemus agrarius. II. Habitats of the striped field mouse in town. Acta Theriol 26:405-415

Baker PJ, Ansell RJ, Dodds PAA, Webber CE, Harris S (2003) Factors affecting the distribution of small mammals in an urban area. Mammal Rev 33:95-100

Baranauskas K, Balciauskas L, Mazeikyte R (2005) Vilnius city theriofauna. Acta Zool Lithuan 15:228-238

Beninde J, Veith M, Hochkirch A (2015) Biodiversity in cities needs space: a meta-analysis of factors determining intra-urban biodiversity variation. Ecol Lett 18:581-592

Bonthoux S, Brun M, Di Pietro F, Greulich S, Bouché-Pillon S (2014) How can wastelands promote biodiversity in cities? A review. Landsc Urban Plan 132:79-88

Bryant MM (2006) Urban landscape conservation and the role of ecological greenways at local and metropolitan scales. Landsc Urban Plan 76:23-44

Cavia R, Cueto GR, Suárez OV (2009) Changes in rodent communities according to the landscape structure in an urban ecosystem. Landsc Urban Plan 90:11-19

Colding J (2007) 'ecological land-use complementation' for building resilience in urban ecosystems. Landsc Urban Plan 81:46-55

CSO (Central Statistical Office) (2014) Area and population in the territorial profile in 2014. Central Statistical Office (CSO), Methodology, Standards and Registers Department. Warsaw

Dickman CR, Doncaster CP (1989) The ecology of small mammals in urban habitats. II. Demography and dispersal. J Anim Ecol 58:119 127

Ditchkoff SS, Saalfeld ST, Gibson CJ (2006) Animal behavior in urban ecosystems: modifications due to human-induced stress. Urban Ecosyst. 9: 5-12

Elek Z, Lövei G (2007) Patterns in ground beetle (Coleoptera: Carabidae) assemblages along an urbanisation gradient in Denmark. Acta Oecologia 32:104-111

Elvers H, Elvers KL (1984) Verbreitung und Ökologie der Waldmaus (Apodemus sylvaticus) in Berlin (West). Zool Beitr 28:403-415

Faeth SH, Bang C, Saari S (2011) Urban biodiversity: patterns and mechanisms. Ann. N.Y. Acad Sci 1223:69-81

Ferenc M, Sedlácek O, Fuchs R, Dinetti M, Fraissinet M, Storch D (2014) Are cities different? Patterns of species richness and beta diversity of urban bird communities and regional species assemblages in Europe. Glob Ecol Biogeogr 23:479-489

Fleury AI, Brown RD (1997) A framework for the design of wildlife conservation corridors with specific application to southwestern Ontario. Landsc Urban Plan 37:163-186 
Francis RA, Chadwick MA (2012) What makes a species synurbic? Appl Geogr 32:514-521

Frynta D, Vohralik V, Reznicek J (1994) Small mammals (Insectivora, Rodentia) in the city of Prague: distributional patterns. Acta Soc Zool Bohem 58:151-176

Gagné SA, Fahrig L (2011) Do birds and beetles show similar responses to urbanization? Ecol. Applications 21:2297-2312

Garden JG, Mcalpine CA, Possingham HP et al (2007) Habitat structure is more important than vegetation composition for local-level management of native terrestrial reptile and small mammal species living in urbanremnants: a case study from Brisbane, Australia. Austral Ecol 32(6):669-685

Garden JG, Mcalpine CA, Possingham HP (2010) Multi-scaled habitat considerations for conserving urban biodiversity: native reptiles and small mammals in Brisbane. Australia Landsc Ecol 25(7):1013-1028

Gliwicz J, Goszczynski J, Luniak M (1994) Characteristic features of animal populations under synurbization - the case of the blackbird and of the striped field mouse. Memorabilia Zoologica 49:237-244

Gomes V, Ribeiro R, Carretero MA (2011) Effects of urban habitat fragmentation on common small mammals: species vs. communities. BiodivConserv 20:3577-3590

Gortat T, Barkowska M, Gryczynska-Siemiatkowska A, Pieniazek A, Kozakiewicz A, Kozakiewicz M (2014) The effects of urbanization - small mammal communities in a gradient of human pressure in Warsaw city, Poland. Pol J Ecol 62:163-172

Helden AJ, Stamp GC, Leather SR (2012) Urban biodiversity: comparison of insect assemblages on native and non-native trees. Urban Ecosyst. 15:611-624

Hobbs RJ et al (2006) Novel ecosystems: theoretical and management aspects of the new ecological world order. Glob Ecol Biogeogr $15: 1-7$

Jones EL, Leather SR (2012) Invertebrates in urban areas: a review. Eur J Entomol 109:463-478

Kong F, Yin H, Nakagoshi N, Zong Y (2010) Urban green space network development for biodiversity conservation: identification based on graph theory and gravity modeling. Landsc Urban Plan 95:16-27

Lattman H, Bergman KO, Rapp M, Tälle M, Westerberg L, Milberg P (2014) Decline in lichen biodiversity on oak trunks due to urbanization. Nord J Bot 32(4):518-528

Lepczyk CA, Mertig AG, Liu J (2003) Landowners and cat predation across rural-to-urban landscapes. Biol Conserv 115:191-201

Łopucki R, Kiersztyn A (2015) Urban green space conservation and management based on biodiversity of terrestrial fauna - a decision support tool. Urban For Urban Greening 14:508-518

Łopucki R, Kitowski I (2014) The occurrence of the Bicoloured WhiteToothed Shrew Crocidura leucodon (Hermann, 1780) in cities of eastern Poland. In: Indykiewicz P, Böhner J (eds) Urban fauna. Animal, Man, and the City - Interactions and Relationships. Bydgoszcz 325-332

Łopucki R, Mróz I, Berliński Ł, Burzych M (2013) Effects of urbanization on small-mammal communities and the population structure of synurbic species: an example of a medium-sized city. Can J Zool 91: 554-561

Luniak M (2004) Synurbization-adaptation of animal wildlife to urban development. In: Shaw WW, Harris KL, VanDruff L (eds) Urban wildlife conservation. Proc. of the 4th Intern. Symp, Univ. of Arizona, Tucson, p 50-55

Magura T, Tóthmérész B, Molnár T (2004) Changes in carabid beetle assemblages along an urbanisation gradient in the city of Debrecen, Hungary. Landsc Ecol 19:747-759

Mahan CG, O'Connell TJ (2005) Small mammal use of suburban and urban parks in Central Pennsylvania. Northeastern Nat 12:307-314

Major RE, Gowing G, Kendal CE (1996) Nest predation in Australian urban environments and the role of the pied Currawong, Strepera graculina. Aust J Ecol 21:399-409
McDonnell MJ, Hahs AK (2008) The use of gradient analysis studies in advancing our understanding of the ecology of urbanizing landscapes: current status and future directions. Landscape Ecol 23: 1143-1155

McDonnell MJ, Pickett STA (1990) Ecosystem structure and function along urban-rural gradients: an unexploited opportunity for ecology. Ecology 71:1232-1237

McKinney ML (2008) Effects of urbanization on species richness: a review of plants and animals. Urban Ecosyst. 11:161-176

Møller AP (2009) Successful city dwellers: a comparative study of the ecological characteristics of urban birds in the western Palearctic. Oecologia 159:849-858

Niemelä J, Kotze DJ (2009) Carabid beetle assemblages along urban to rural gradients: a review. Landsc Urban Plan 92:65-71

Nilon CH, Pais RC (1997) Terrestrial vertebrates in urban ecosystems: developing hypotheses for the Gwynns falls watershed in Baltimore, Maryland. Urban Ecosyst. 1:247-257

Peressin A, Cetra M (2014) Responses of the ichthyofauna to urbanization in two urban areas in Southeast Brazil. Urban Ecosyst. 17:675-690

Rebele F (1994) Urban ecology and special features of urban ecosystems. Glob Ecol Biogeogr Lett 4:173-187

Sandström UG, Angelstam P, Mikusiński G (2006) Ecological diversity of birds in relation to the structure of urban green space. Landsc Urban Plan 77:39-53

Secretariat of the Convention on Biological Diversity (2012) Cities and Biodiversity Outlook. Montreal, 64 pages. http://www.cbd. int/en/subnational/resources/documents

Seto K, Guneralp B, Hutyra LR (2012) Global forecasts of urban expansion to 2030 and direct impacts on biodiversity and carbon pools. PNAS 109(40):16083-16088

Sorace A (2001) Value to wildlife of urban-agricultural parks: a case study from Rome urban area. Environ Management 28:547-560

Sorace A, Gustin M (2010) Bird species of conservation concern along urban gradients in Italy. Biodivers Conserv 19:205-221

Sun PJ, Xiu CL, Wang Q, Ding SB (2012) Study on the non-conformity of urban spatial expansion in China. Prog Geogr 31:1032-1041

Sushinsky JR, Rhodes JR, Possingham HP, Gill TK, Fuller RA (2013) How should we grow cities to minimize their biodiversity impacts? Glob Chang Biol 19:401-410

United Nations (2015) Department of Economic and Social Affairs, Population Division. World Urbanization Prospects: The 2014 Revision, (ST/ESA/SER.A/366)

van der Ree R, McCarthy MA (2005) Inferring persistence of indigenous mammals in response to urbanization. Anim Conserv 8:309-319

VanDruff LW, Rowse RN (1986) Habitat association of mammals in Syracuse, New York. Urban Ecol 9:413-434

Vergnes A, Kerbiriou C, Clergeau P (2013) Ecological corridors also operate in an urban matrix: a test case with garden shrews. Urban Ecosyst 16:511-525

Vergnes A, Pellissier V, Lemperiere G, Rollard C, Clergeau P (2014) Urban densification causes the decline of ground-dwelling arthropods. Biodivers Conserv 23:1859-1877

Vignoli L, Mocaer I, Luiselli L, Bologna MA (2009) Can a large metropolis sustain complex herpetofauna communities? An analysis of the suitability of green space fragments in Rome. Anim Conserv 12: 456-466

Wang G, Zuo J, Li XR, Liu Y, Yu J, Shao H, Li Y (2014) Low plant diversity and floristic homogenization in fast-urbanizing towns in Shandong peninsular, China: effects of urban greening at regional scale for ecological engineering. Ecol. Engineering 64:179-185

WPR (2015) http://worldpopulationreview.com

Yu D, Xun B, Shi P, Shao H, Liu Y (2012) Ecological restoration planning based on connectivity in an urban area. Ecol Engineering 46:24-33 